\title{
Balkanologie
}

Balkanologie Revue d'études pluridisciplinaires

Vol. II, nº 2 | 1998

Volume II Numéro 2

\section{The Emigration of Muslims from the New Serbian Regions 1877/1878}

\section{Miloš Jagodić}

\section{(2) OpenEdition \\ 1 Journals}

\section{Electronic version}

URL: http://journals.openedition.org/balkanologie/265

DOI: 10.4000/balkanologie.265

ISSN: 1965-0582

\section{Publisher}

Association française d'études sur les Balkans (Afebalk)

\section{Printed version}

Date of publication: 1 December 1998

ISSN: 1279-7952

\section{Electronic reference}

Miloš Jagodić, "The Emigration of Muslims from the New Serbian Regions 1877/1878 », Balkanologie [Online], Vol. II, $n^{\circ} 2$ | 1998, Online since 02 June 2008, connection on 17 December 2020. URL : http:// journals.openedition.org/balkanologie/265; DOI : https://doi.org/10.4000/balkanologie.265

This text was automatically generated on 17 December 2020 .

(c) Tous droits réservés 


\title{
The Emigration of Muslims from the New Serbian Regions 1877/1878
}

\author{
Miloš Jagodić
}

1 During the Great Eastern crisis 1875/1878, a large migration process was going on in the Balkans. It is estimated that, about two million people, half Christians, half Muslims, left their homes at that time ${ }^{1}$. The Muslim population was withdrawing from Bulgaria, Bosnia and Herzegovina and from the regions attached to Serbia by the Berlin treaty. The inner provinces of the Ottoman Empire were their final destination. The Muslims' emigration from Serbia was not as big as the ones from the other mentioned areas, but still, it was not of less importance ${ }^{2}$.

2 My paper is based on the published Serbian and Turkish inventories, Serbian archive documents and on some travels from that period. V. N. Stojančević and R. L. Pavlović have dealt with this particular subject, while the few other Serbian authors have causally mentioned various data about this topic in their works.

3 Serbia was twice at war with Turkey during the Eastern crisis. She was defeated in the first one in 1876. The consequences were disastrous. About 200000 people, war victims and refugees from Turkey, remained homeless after that war ${ }^{3}$. In the period between the two wars, Austria-Hungary and Russia made agreements about the division of the spheres of interest in the Balkan Peninsula. According to the treaties signed by the two Powers, Bosnia and Herzegovina were left to Austria. Therefore, the Serbian expansion in these areas was disabled. On the other hand, Russia was interested in the eastern part of the Balkans ${ }^{4}$. In such international circumstances, Serbia was forced to seek space south of its borders, in the large area, called the Old Serbia. In the second war with Turkey 1877/1878, Serbia was a Russian ally. She entered the war on Russia's request ${ }^{5}$. This time, the Serbian army conquered significant territories south and southeast of the Serbian-Turkish border. It was decided in Berlin that Serbia should keep most of its war possessions ${ }^{6}$. These new Serbian regions were placed between the cities Kuršumlja, Pirot and Vranje, in the South Morava and Nišava basins ${ }^{7}$. They were administratively divided into four counties : Niš, Pirot, Vranje and Toplica. 


\section{Ethnical Structure of the New Serbian Counties before the $1877 / 1878$ War}

4 Before the war, these counties had been administratively included into the sanjak of Niš, which had been a part of the Kosovo vilayet. A Turkish inventory, made in 1873, gives a general picture about the confessional and, partly, ethnical structure of their population 8 .

Table 1

\begin{tabular}{|l|l|l|l|l|}
\hline & \multicolumn{2}{|l|}{ Number of men } & \multicolumn{2}{l|}{ Number of houses in cities } \\
\hline District & Christians & Muslims & Serbian & Muslims \\
\hline Niš & 17107 & 4291 & 3500 & 2000 \\
\hline Pirot & 29741 & 5772 & 3000 & 400 \\
\hline Vranje & 30061 & 12502 & 2500 & 800 \\
\hline Leskovac & 21030 & 10525 & 2500 & 1000 \\
\hline Prokuplje & 4618 & 6207 & 140 & 650 \\
\hline \hline Kuršumlja & 757 & 5951 & 0 & 150 \\
\hline Trn & 7072 & 149 & 300 & 15 \\
\hline Total & 110386 & 46027 & 11940 & 5015 \\
\hline \hline & 156413 & & 16955 \\
\hline
\end{tabular}

\begin{tabular}{|l|l|l|}
\hline \multicolumn{2}{|l|}{ Number of inhabitants in cities } & Language of Muslim population in cities \\
\hline Niš & 18255 & Turkish \\
\hline Pirot & 10975 & Turkish \\
\hline Vranje & 10345 & $1 / 2$ Turkish, $1 / 2$ Albanian \\
\hline Leskovac & 13445 & $1 / 2$ Turkish, $1 / 2$ Albanian \\
\hline Prokuplje & 4410 & Albanian \\
\hline Kuršumlja & 900 & Albanian \\
\hline Trn & & Albanian \\
\hline Total & 58330 & \\
\hline
\end{tabular}


5 The Christian male population made $70,57 \%$ and the Muslim made $29,43 \%$ of the entire male population. The Muslims were in majority in the districts of Kuršumlja and Prokuplje. In the first, there was $88,7 \%$ of them and $57,34 \%$ in the second. In the other districts, the Christians were in majority, but the percentage of Muslims was not small in any of them. In the district of Leskovac, the Muslim male inhabitants made 33,35\%, and in the district of Vranje $29,37 \%$ of the whole male population. The smallest number of them was in the district of Pirot, $16,25 \%$, and Trn, $2,06 \%$.

6 According to the information about the language spoken among the Muslims in the cities, we can see of which nationality they were. So, the Muslim population of Niš and Pirot consisted mostly of Turks; in Vranje and Leskovac they were Turks and Albanians ; Muslims in Prokuplje and Kuršumlja were mostly Albanians.

Unfortunately, we do not know the exact number of all the Niš sanjak's inhabitants. We can only presume that the number of women was, approximately, equal as the number of men. Then, it follows that, about, 312826 people lived in the sanjak of Niš, in 1873 : 220772 Christians and 92054 Muslims.

8 These data can be compared with the Kosovo vilayet inventory, made in 1877. According to this statistics, the sanjak of Niš had 143814 inhabitants and the sanjak of Pirot had 93241 ; together, they had 237055 inhabitants ${ }^{9}$. These two sanjaks comprised the same territory as the sanjak of Niš in 1873, but without the district (kaza) of Vranje, which was in the meantime attached to the sanjak of Priština ${ }^{10}$. When the number of inhabitants of that district is excluded from the 1873 inventory, then we get the number of approximately 227700 people. So, the population of the 1873 Niš sanjak, without the Vranje district, has increased by $4,1 \%$ in the $1873-1877$ period. If this increase is by analogy applied to the district of Vranje, then it would have had about, 88616 inhabitants in 1877 . When we add that number to the number of inhabitants of the 1877 Niš and Pirot sanjaks, then we get the approximate number of people, who lived on the 1873 Niš sanjak's territory, in 1877, which is 325671 . In order to find out how many people lived on the territory of four new Serbian counties in 1877, we must substract the number of Trn district's inhabitants from 325 671, for that district was given to Bulgaria by the Berlin treaty. It had 15034 inhabitants in $1877^{11}$, which means that, before the war, about, 310736 people lived in the regions attached to Serbia. There were approximately 215117 Christians and 95619 Muslims $^{12}$.

The Muslims from the districts Prokuplje and Kurshumlja were mostly Albanians. The area they inhabited was confined by the Toplica river valley on the north, Kopaonik on the southwest and the South Morava valley on the east and southeast. The Serbs in that area lived only near the river mouths and on the mountain slopes ${ }^{13}$. The Albanian settlements could have been found also on the right bank of the South Morava, in the region called Masurica ${ }^{14}$. Some Albanians lived even in Trn, a small town in the west of Bulgaria $^{15}$.

10 The migration of Albanians towards the northeast started after the Serbs had moved into Hungary, in 1690 and $1737^{16}$. Having settled in Kosovo, they began to cross the Golak mountain in the second half of the $18^{\text {th }}$ century and to inhabit the mentioned $\operatorname{area}^{17}$.

11 The Turks have been mostly city dwellers. It is certain, however, that part of them was of Albanian origin, because of the well-known fact that the Albanians have been very easily assimilated with Turks in the cities ${ }^{18}$. 


\section{Causes of Emigration} to spread over the Peninsula, as it was the case with the settling of Albanians in Kosovo, Macedonia and Toplica ${ }^{19}$. In the $19^{\text {th }}$ century, Muslims were colonized by plan, in order to separate the homogeneous Christian regions from each other. That was the policy of replacing the unreliable population with the more suitable ones. When Russia had finished conquering Caucasus, it expelled almost the entire Czerkes nation from its land. These Muslims moved into Turkey in the $19^{\text {th }}$ century sixties. Part of them was colonized in the Balkans, mostly in Bulgaria, but also near the Serbian border, around Niš, Pirot and in Kosovo. Serbia was, in that way, surrounded by Czerkes' settlements in the northeast and by Albanians in the southwest. That continuous Muslim zone separated Serbia from the Christians in Bulgaria, Macedonia and Kosovo ${ }^{20}$. The Turks, who left the Serbian cities in 1862 , were colonized by the Porte along the borderline rivers, the Una, the Sava and the Drina, and in the surroundings of Niš and Vidin, which were close to the Serbian border at that time ${ }^{21}$.

During the $19^{\text {th }}$ century, the Muslims in the Balkans had been emigrating from the territories, which would have stopped being an integral part of the Ottoman Empire. Such migrations were mostly the consequence of the wars. Their directions were identical with the expanding directions of the Christian Balkan countries. Muslims were simply not able to accept the way of life in these young, European-like organized states. Besides, they were afraid of becoming inferior citizens, like Christians in Turkey. In most cases, the compromise was not possible. Therefore, Muslims were emigrating from the territories deserted by the Ottoman army. Sometimes, the Turkish generals used to call the Muslim population to come along with the withdrawing troops, into the Sultan's land ${ }^{22}$.

In the 1877/1878 war, the main Turkish force against Serbia consisted of Albanians. They were organized in 72 units, with 550 men each $^{23}$. They came mostly from Kosovo and Macedonia. On the other hand, Albanians from Prokuplje, Kuršumlja and Leskovac districts were not organized in the military formations. They fought independently of the Turkish army. Divided into small groups, they were defending every village, every house. Each one of them defended his own doorstep. That was the reason why their villages were, so thoroughly, "cleaned" ${ }^{24}$. The city Muslims were not resisting the Serbian army, but only withdrawing along with the regular Turkish troops.

Not all Albanians had moved out in front of the advancing Serbian army. A part of them had surrendered just before the end of the war, and some had not even fought at all. Such Albanians stayed in their homes. A certain number of the Albanian refugees returned to their villages, after the armistice had been arranged. Almost all of these people were expelled to Turkey after the Berlin congress ${ }^{25}$. The young Christian countries, Serbia in this case, did not wish to have Muslims within their territories. The Serbian Government considered the Albanians as an undesirable and unreliable population, which had to be replaced with a more convenient one. Such policy was quite usual in the Balkans at that time. The Serbian Prime Minister, Jovan Ristić, thought that Serbia should be an ethnically homogeneous country. Besides, the territories inhabited by Albanians were of strategic importance. They were supposed to be the base for future expansion towards the old Serbia and Macedonia. Therefore, it

Balkanologie, Vol. II, n² 2 | 1998 
was necessary to populate them with the reliable population. One of the Serbian generals, Kosta Protić, stated then that he did not want Serbia to have its own Caucasus $^{26}$.

\section{The Emigration Process} army's advancing. towards Kuršumlja ${ }^{30}$. wagons ${ }^{31}$. return to their homes. Serbian authorities ${ }^{39}$.

Most of the Muslims moved out during the military operations. Therefore, the migration directions were, more or less, identical to the directions of the Serbian

Serbian forces crossed the border on 15 . December $1877^{27}$, penetrating in two main directions. The first was pointed to the south, towards Niš, in order to besiege the town. The second was southeastern, towards Pirot and Sofia ; the aim was to cut the Niš-Sofia line of communication, for the Russians could more easily take that town. Niš was besieged quickly. A part of the troops operating on the south direction had to penetrate into the Toplica valley to prevent the Turkish break-through from Kosovo to Niš.

The Serbs took Prokuplje on the third day of the $w^{28}{ }^{28}$. Muslims from the town and surroundings, mostly Albanians, left their homes in panic, leaving large quantities of food and cattle behind ${ }^{29}$. Local Albanians escaped to the mountain Pasjača, south of Prokuplje. One part of these refugees returned soon to their villages, submitting themselves to the Serbian authorities, while the others kept on moving southwest,

During the further advancing towards Kuršumlja, the Serbian troops came across the Albanian refugees, who were spread all over the adjacent mountains. While retreating, they were resisting the Serbs and refusing to surrender. Sometimes, in panic, the refugees left wagons full of different kinds of personal belongings in the woods to move faster. Serbian soldiers found once a two year old child, almost frozen, in one of these

Kuršumlja was seized soon after Prokuplje. The refugees had already reached the south slopes of Kopaonik. Turkish forces tried to make a breach through the Toplica valley, in order to send help to the besieged Niš, so the area around Kuršumlja became a battlefield. Therefore, the escaped Albanians were forced to remain in the mountains. They were waiting for the Serbs to be pushed out of their villages ${ }^{32}$. It turned out they were waiting in vain. Niš was seized, the Turks withdrew ${ }^{33}$ and the refugees did not

21 Having besieged Niš, Serbs sent a part of the forces down the South Morava valley, towards Leskovac. The Muslims left town as soon as they heard that the army was approaching. While preparing to escape, they took the wagons and about a thousand oxen from the local Serbian peasants. They went south, towards Vranje and Skoplje ${ }^{34}$. There were only 62 poor Muslim families remained, when the Serbs entered the town ${ }^{35}$.

In the meantime, the Serbian army seized Pirot. The Muslims went to Kosovo and Macedonia. Some of them even reached Thracia ${ }^{36}$.

The Turks in Niš surrendered on 10. January 1878. It was allowed for those who wished, to leave the town peacefully ${ }^{37}$. The Muslims went to Priština, Prizren, Skoplje and Saloniki ${ }^{38}$. The remained Turks were mostly poor and they received food from the local 
24 After the seizure of Niš, the Serbian troops were divided in two groups. The first had to advance southwest, down the valleys of the Toplica, Kosanica, Pusta Reka and Jablanica (the South Morava tributaries), while the second one had to go south, down the South Morava valley, to seize Vranje and then to turn west. Their mutual task was to penetrate Kosovo $^{40}$. Both directions were leading across the regions inhabited by the Albanians.

The advancing of the army on the southwest was very slow, because of the hilly ground and permanent fights with the local Albanians. They had sheltered their families on the adjacent mountains Radan and Majdan and then they came back to defend their villages. Therefore, the Serbs were forced to conquer them one by one. Because of such a hard resistance, the Albanian villages remained completely vacant. The refugees were slowly retreating to Kosovo, across the Golak mountain. They eventually reached the Priština region, which turned out to be their final destination. The Serbs did not manage to breach on Kosovo. The armistice stopped them on the peaks of Golak ${ }^{41}$.

The army operating on the south direction had to break through the two canyons: Grdelica (between Vranje and Leskovac), and Veternica (southwest of Grdelica). After the battles for Grdelica and in front of Vranje, the Serbs took this city ${ }^{42}$. The Muslims from Vranje had taken the cattle, food and money from the local Serbs before they left ${ }^{43}$. A lot of Muslims moved out from the Vranje surroundings in the following months, for they were exposed to all sorts of disturbances from their Serbian neighbours ${ }^{44}$. The Albanians defended the Veternica canyon, while their families were sheltered on the Golak mountain. They came to the same mountain, after they had been forced to leave the canyon ${ }^{45}$. A smaller part of the Albanians escaped towards Vranje ${ }^{46}$. The local Serbs took part in the fighting around Veternica. They showed a great hostility towards the Albanians by burning their houses, looting and chasing them ${ }^{47}$. The Albanians on the right Morava bank, in the region called Masurica, did not resist and remained in their villages ${ }^{48}$.

27 After the seizure of Vranje, the Serbian troops turned west, towards Kosovo and they almost reached Priština. The armistice between the Russians and the Turks stopped them in front of the city. The Albanians inhabited the territory between Vranje and Priština did not take part in fighting and they remained in their homes ${ }^{49}$.

I am not able to describe the emigration of the Muslims after the Berlin congress, for the lack of reliable sources. A small number of them were expelled after the war, since the majority had left during the military operations. Some influential officers initiated and supported such government measures. Only general Jovan Belimarković was opposed to the expulsion orders. He did not allow the Albanians from Masurica to be moved out. But, they were expelled a bit later, when the general was on the leave. The only compact group of Albanians remained in the Jablanica valley. They were lucky to have introduced themselves to Prince Milan Obrenović before the Berlin treaty was signed, so they enjoyed his personal protection afterwards ${ }^{50}$. In Niš, for example, the local administrative clerks mistreated the remaining Muslims, so they were forced to emigrate $^{51}$. 


\section{Settling of Muslim Refugees in Turkey}

29 The Albanian refugees (Turk. muchageers) were mostly settled in the Lab region and in the north of Kosovo, next to the new Turkey-Serbia border ${ }^{52}$. The Serbian population from Lab had moved to Serbia during and after the war in 1876 and then the Albanians inhabited their villages ${ }^{53}$. Most of the refugees were settled in the Priština region and less in the regions of Vučitrn, Uroševac (Ferizović) and the upper Morava ${ }^{54}$. There were 31 Serbian-muchageer and 3 pure muchageer villages in the area southwest of the Serbian border, between Novo Brdo, the Kriva River, Gnilan and the Little Morava ${ }^{55}$.

A considerable number of refugees settled in Priština; those from Niš and Leskovac soon became quite influential in that town ${ }^{56}$. Besides Priština, the muchageers from Leskovac moved also into the other Kosovo and Macedonia cities. The Muslims from Pirot immigrated to the same regions, while some even settled in Istanbul ${ }^{57}$.

The refugees in Kosovo were not well accepted by the Turkish authorities. They were usually settled on swampy or wooded land, which needed to be cultivated ${ }^{58}$. The refugees slowly created their own settlements within or beside the already existing (in many cases Serbian) villages, along the Serbia-Turkey border. The native Muslims (Turk. yerlias) did not gladly accept the refugees, who they considered to have been less valuable than them. The mutual quarrels, fights and even murders were not rare ${ }^{59}$. The relations between the native Muslims and refugees were not much better in the cities either. In Priština, the Turks had been complaining that everything went wrong, since the refugees had arrived. They did not even consider the muchageers as Turks. The reason for such a behavior should be looked for in the natives' conservatism, since certain differences in customs existed between them and the newcomers. The refugees, for example, did not use to hide women, like the natives. Besides, they changed the common way of trading. The old one, based on trust and the given word, had vanished. The refugees introduced receipts, written contracts and interests, which were new and strange to the natives ${ }^{60}$. It is certain that the muchageers from Niš and Leskovac overtook a great deal of trade in Priština. It seems, however, that they overtook it from the local Serbs and not from the Turks ${ }^{61}$. It is likely that the same thing also happened in Prizren and Pećc ${ }^{62}$. The refugees in Kosovo used to name themselves after the places from which they had come from. They also used to give the same names to their new settlements. The refugees and their descendants could have been, therefore, easily recognized fifty years after the migration ${ }^{63}$.

\section{Number of Muslim Emigrants}

It is not possible to establish the exact number of Muslims who emigrated from Serbia. It is even less possible to speak about the number of Albanians, Turks or Czerkes, who moved out. I can only try to estimate the approximate number of Muslim emigrants, relying on the Serbian archive documents and travels.

As far as I know, there is only one anticipation about the number of refugees and it is accepted in the Serbian historiography. J. Cvijić suggested that there were about 30000 Albanian refugees ${ }^{64}$. I believe that the number of Albanians and Muslims in general, who emigrated from the new counties of Serbia, was much larger. 

was administratively divided into six counties: Niš, which had the districts Niš, Koprivnica and Bela Palanka; Kuršumlja, which had the districts Prokuplje, Kuršumlia, Ibar and Vučitrn; Leskovac, which had the districts Veternica, Vlasotince and Pusta Reka; Vranje, which had the districts Vlasina, Poljanica, Morava and Pćinja; Pirot, which had the districts Nišava, Visočki, Breznik, Trn and Lužnica; Kula, which had the districts Kula and Novoselo ${ }^{65}$. According to the Berlin treaty, the districts Trn, Ibar and Vučitrn, as well as the whole Kula county remained out of Serbia's borders. After the Congress, the new administrative division on four counties (Niš, Pirot, Vranje and Toplica) was established and it entered the first official state statistics ${ }^{66}$. I will be dealing here with the first division. One of the first duties of the new Serbian local authorities was to make the inventories of the districts and to create temporary communities. After they had completed that task, they sent reports to the Minister of education ${ }^{67}$. I have tried to establish the approximate number of Muslims who left according to these reports, which show the exact picture of the occupied territories, just after the end of the war. Besides them, I have also used some travels from that time.

\section{The District of Prokuplje}

The report of the local authorities, dated 31. March (12. April) 1878, to the Minister of education, Alimpje Vasiljević, contains the following data about the district's cities, villages and population ${ }^{68}$ :

\begin{tabular}{|l|l|l|l|l|l|}
\hline & & \multicolumn{3}{|c|}{ Number of houses } & \multicolumn{2}{l|}{ Number of inhabitants } \\
\hline & Settlements & Serbian & Muslim & Serbs & Muslims \\
\hline \hline Villages & 131 & 1485 & 1553 & 12077 & 987 \\
\hline Cities & 1 & 364 & 750 & 1804 & 0 \\
\hline Total & 132 & 1849 & 2303 & 13881 & 987 \\
\hline
\end{tabular}

According to this inventory, there were 131 settlements in the district, among which Prokuplje was the only town. I shall be dealing only with the villages at the moment, and come back to the cities later. The number of houses in twelve villages remained unregistered, for those villages could not have been reached because of the snow. However, it is stated in the report that those villages were Albanian and that they were all abandoned ${ }^{69}$. Therefore, the number of houses in the district's villages refers to 119 of them. It can be presumed that the Albanians ${ }^{70}$, who lived here, had as big families as their neighbours, the Serbs, for they all lived in the extended family groups. The average number of inhabitants in one Serbian house was $8(8,13)$. If that relation is applied to the Albanian houses also, then it follows that about 11437 Albanians moved out from 119 villages of the Prokuplje district ${ }^{71}$. 


\section{The District of Kuršumlja}

37 The local authorities of this district did not make an inventory. Therefore, we shall rely on the data from M. Rakić's travels. There were 127 villages in the district and Kuršumlia was the only town, but it remained completely vacant after the war. The Muslims who left were the Albanians. Here are the data about the number of houses and inhabitants in the district ${ }^{72}$ :

38 The number of remaining Muslim population is not stated. It is likely that all of them moved out, considering the battles, which had been going on in the area. The houses of Kuršumlja are probably included in the whole number, for the author did not consider Kuršumlja to be a real town ${ }^{73}$. One Serbian house had about $9(9,12)$ inhabitants. If the same relation is applied to the Albanian houses as well, then it follows that approximately 17604 Albanians left the district.

The Kuršumlja county had two more districts, Ibar and Vučitrn. Since they were not attached to Serbia, I shall not discuss them here.

\section{The County of Leskovac}

40 The chief of the Leskovac county administration made a list of settlements and houses in his administrative area and sent it as a report to the Minister of education on 14. (26) March $1878^{74}$. According to this inventory, there were 221 settlements and 10369 houses in the Leskovac county. Leskovac itself had 2015 inhabited and about 700 empty Muslims' houses. Besides, there were also 53 abandoned Albanian villages, which were not included in the previously mentioned number of settlements. They were placed in the region called Pusta Reka ${ }^{75}$. Apart from these villages, the Albanians lived in three more communities next to them. These communities comprised 45 villages, of which 14 purely Albanian, 10 Serbian, 17 with a mixed population and there are no data for the 4 remained. There were 542 Serbian and 691 Albanian houses in these 41 villages. The last ones were vacant. The chief of the county administration stated in the report that in the 53 empty villages might have been approximately 30 houses each. The average number of houses in the mentioned 41 villages was $27(27,4)$. Since they were next to the empty ones, that relation can be applied to them also, which means that they had about 1431 houses. Then, it follows that there were 2122 vacant Albanian houses altogether in the villages of the Leskovac county. The number of inhabitants is not stated in the report, but it can be presumed that the families had approximately 8 members, like in the other counties. In the Pusta Reka district, which was established after the Berlin congress, the average number of inhabitants in one house was exactly $8^{76}$, which confirms the previous assumption. Therefore, it follows that about 16976 Albanians moved out from the villages of the Leskovac county.

41 The territory of this county was identical with the one of the former Turkish Leskovac district $^{77}$. This fact gives the opportunity to check the stated estimations about the number of emigrants. About 17033 Muslims lived in the villages of the Leskovac district in $1877^{78}$, which means that the mentioned assumption is correct. 


\section{The County of Vranje} of the Vranje county before 1878. I know only that 817 Albanians remained in 8 villages of the Masurica region ${ }^{79}$. According to the antropogeographic researches of R. T. Nikolić, done at the beginning of the $20^{\text {th }}$ century, there were 7 Albanian villages in Masurica, 8 in the Vranje surroundings, 1 in the Vinogos region ${ }^{80}$ and approximately 230-250 Albanian houses in the region called Poljanica ${ }^{81}$. About 1 700-1 900 Albanians might have lived in the last of the mentioned regions ${ }^{82}$. Still, according to the stated data, I am not able to even estimate the whole number of Albanians, who emigrated from the villages of this district.

\section{The County of Niš}

The local authorities of the Koprivnica district made an inventory of the villages on their administrative territory. There were 80 villages, inhabited by the Serbs. They worked on the land, which mostly belonged to the Turks. 26 Turks, landowners, of whom four had residences in Niš, are listed in the inventory ${ }^{83}$. There is not this sort of data for the second, Niš, district of the county. It was placed on the right bank of the river Nišava and there was a certain number of abandoned Czerckes' villages on its territory ${ }^{84}$. However, it is not possible to say how many of them were there, or how many people left them.

\section{The District of Bela Palanka and the County of Pirot}

There were some vacant Czerckes' settlements in the vicinity of Bela Palanka, on the right bank of the Nišava, but their number can not be established according to the available sources ${ }^{85}$. The fortress of Bela Palanka was inhabited by the Turks, who escaped towards Leskovac; unfortunately, their number remains unknown ${ }^{86}$. I am not able to say anything specific about the ethnical structure of the Pirot county in the prewar period, except that there were also some Czerckes' villages ${ }^{87}$.

\section{The Cities}

The Muslim rural population was mostly ethnically homogeneous in certain regions, like the Albanians in the Pusta Reka district, for instance. That was not the case in the cities. Here, it is impossible to divide the Muslims by nationalities (except in Prokuplje), for the sources treat them all as "the Turks", which was a synonym for "the Muslims". Therefore, I have chosen to deal separately with the number of the Muslims who emigrated from the cities.

According to the previously mentioned report of the Prokuplje district's administration, there were 1114 houses in the city, 364 Serbian and 750 empty Muslim houses. 1804 inhabitants remained and they were all Serbs ${ }^{88}$. The data stated in the M. Rakić's travels differ a bit. The total number of houses and inhabitants is identical, but the relation between the Serbian and the Muslims' houses is not: 405 Turkish, 299 Albanian and 440 Serbian houses ${ }^{89}$. If the same method as used before is applied ${ }^{90}$, it follows that approximately 1226 Albanians and 1660 Turks, or 2886 Muslims, 
emigrated from Prokuplje. This figure matches the number of the city inhabitants in $1877^{91}$, so it can be accepted as correct.

There were about 900 Muslims' houses and approximately 5000 Muslims in Leskovac before the war. According to the first Serbian official statistics, in the beginning of 1879, there were 120 Muslims left in the city ${ }^{92}$, which means that 4880 of them had moved out.

Only 878 Muslims had stayed in Vranje after the war, but many of them emigrated in the following months. There were 860 Serbian houses with 5805 inhabitants and 991 Muslims' houses in the town ${ }^{93}$. One Serbian family had approximately 6,75 members. If the same relation is applied to the Muslims' houses, it follows that about 6690 of them lived in Vranje before the war. There were 437 Muslims remaining in $1879^{94}$, which means that approximately 6250 had emigrated.

Before the war, there were about 8500 Muslims in Niš. 1168 of them were listed in the first Serbian inventory in 1879. 797 Gypsy Muslims were probably included in that number ${ }^{95}$. According to the stated data, approximately 7332 Muslims moved out from Niš.

All sources agree that about 2500 Muslims have lived in Pirot, until 1878 ${ }^{96}$. In 1879, there were 638 of them remained in the city ${ }^{97}$, which means that approximately 1862 Muslims emigrated from Pirot after the war.

51 The total number of Muslims, who moved out from the mentioned cities, is approximately 23210 .

When all the mentioned figures are added, it follows that, about 71000 Muslims emigrated from the new Serbia's counties, during or after the war. 49000 of them were surely Albanians. It is certain, however, that the total number of Muslim emigrants was bigger, but for lack of sources it can not be established. There were also more then 49000 emigrants of Albanian nationality, for those from Vranje and Leskovac are not included in that sum. A certain number of them might have lived also in Niš ${ }^{88}$.

53 In order to get a complete picture about the scope of this emigration, I shall now present the data taken from the 1879 inventory ${ }^{99}$.

\begin{tabular}{|l|l|l|l|l|l|}
\hline County & Serbs & Muslims & Jews & $\%$ Muslims & \\
\hline Niš & 115890 & 2445 & 1076 & 2,05 & \\
\hline Pirot & 76892 & 824 & 360 & 1,05 & \\
\hline Vranje & 64844 & 2251 & 0 & 3,35 & \\
\hline Toplica & 42014 & 1047 & 7 & 2,43 & \\
\hline \hline Total & 299640 & 6567 & 1443 & 2,13 & 307650 \\
\hline
\end{tabular}

54 Here are the data about the urban and rural Muslim population in $1879^{100}$ :

\begin{tabular}{|l|l|l|}
\hline County & Muslims & Number of inhabitants \\
\hline
\end{tabular}




\begin{tabular}{|l|l|l|l|l|l|l|}
\hline & Urban & $\%$ & Rural & $\%$ & Urban & Rural \\
\hline Niš & 2019 & 7,13 & 426 & 0,47 & 28310 & 91101 \\
\hline Pirot & 692 & 6,8 & 132 & 0,19 & 10172 & 67904 \\
\hline Vranje & 437 & 5 & 1814 & 3,1 & 8728 & 58367 \\
\hline Toplica & 113 & 3,9 & 934 & 2,32 & 2900 & 40168 \\
\hline Total & 3261 & 6,5 & 3306 & 1,28 & 50110 & 257540 \\
\hline
\end{tabular}

According to these statistics, the absolute biggest number of the Muslims remained in the Niš county. In 1879, this county comprised a part of the former Leskovac county, including that town. The Muslims lived mostly in the cities. The relative biggest number of the Muslims stayed in the Vranje county. Here are the data about the confessional structure of this county ${ }^{101}$ :

\begin{tabular}{|c|r|r|} 
DISTRICT & INHABITANTS & MUSLIMS \\
\hline CITY VRANJE & 8728 & 437 \\
\hline MASURICA & 13791 & 1410 \\
\hline POLJANICA & 16737 & 125 \\
\hline PĆ.INJA & 26025 & 279 \\
\hline
\end{tabular}

Most Muslims remained in the Masurica district. They were the ones, who had surrendered to the Serbian army and waited for the end of the war in their homes.

57 A lot of Muslims stayed also in the Toplica county, which consisted of the former Prokuplje and Kuršumlja districts. However, it should be kept in mind that the Albanians had been the majority in this area before the war. Here are the statistics of the Toplica county ${ }^{102}$ :

\begin{tabular}{|l|l|l|}
\hline District & Inhabitants & Muslims \\
\hline City Prokuplje & 2690 & 130 \\
\hline Dobriča & 14294 & 347 \\
\hline Jablanica & 10448 & 587 \\
\hline Kosanica & 5778 & 0 \\
\hline Prokuplje & 9868 & 0 \\
\hline
\end{tabular}

There were no Muslims left in the Kosanica and Prokuplje districts. Those from the first one had all probably emigrated during the fights around Kuršumlja, but the Muslims from the second one had partly surrendered and returned to their houses. They were obviously expelled later. The Muslims from the Jablanica district enjoyed the special protection of the Prince Milan. 
59 The smallest number of Muslims, absolute and relative, remained in the Pirot county. In comparison with that, there was a large percentage of them left in the city itself $6,8 \%$.

The emigration process was continued during the following few years. Here are the statistic data about these counties, taken from the 1884 inventory ${ }^{103}$ :

\begin{tabular}{|c|c|c|c|c|c|c|c|}
\hline County & Inhabitants & Serbs & Albanians & Turks & \% Albanians & $\%$ Turks & $\%$ Muslims \\
\hline Vranje & 67826 & 65870 & 50 & 11 & 0,07 & 0,01 & 0,09 \\
\hline Niš & 135600 & 130954 & 24 & 375 & 0,01 & 0,27 & 0,29 \\
\hline Pirot & 77922 & 76545 & 0 & 36 & 0 & 0,04 & 0,04 \\
\hline Toplica & 73133 & 69901 & 1742 & 12 & 2,38 & 0,01 & 2,4 \\
\hline \multirow[t]{2}{*}{ Total } & 354481 & 343270 & 1846 & 434 & 0,5 & 0,11 & 0,63 \\
\hline & & & 2250 & & & & \\
\hline
\end{tabular}

\begin{tabular}{|c|c|c|c|c|c|c|c|}
\hline \multicolumn{8}{|c|}{ Rural population } \\
\hline County & Total & Albanians & Turks & Muslims & \% Albanians & $\%$ Turks & \% Muslims \\
\hline Vranje & 58335 & 46 & 0 & 46 & 0,08 & 0 & 0,08 \\
\hline Niš & 105246 & 1 & 1 & 2 & 0 & 0 & 0 \\
\hline Pirot & 67922 & 0 & 0 & 0 & 0 & 0 & 0 \\
\hline Toplica & 68480 & 1741 & 8 & 1749 & 2,5 & 0,01 & 2,5 \\
\hline Total & 299953 & 1788 & 9 & 1797 & 0,6 & 0,003 & 0,6 \\
\hline
\end{tabular}

\begin{tabular}{|c|c|c|c|c|c|c|c|}
\hline \multicolumn{8}{|c|}{ Urban population } \\
\hline County & Total & Albanians & Turks & Muslims & \% Albanians & \% Turks & $\%$ Muslims \\
\hline Vranje & 9491 & 4 & 11 & 15 & 0,04 & 0,1 & 0,15 \\
\hline Niš & 30384 & 23 & 374 & 397 & 0,07 & 1,2 & 1,3 \\
\hline Pirot & 10000 & 0 & 36 & 36 & 0 & 0,36 & 0,36 \\
\hline Toplica & 4653 & 1 & 4 & 5 & 0,02 & 0,08 & 0,1 \\
\hline Total & 54528 & 28 & 425 & 453 & 0,05 & 0,7 & 0,8 \\
\hline
\end{tabular}


61

were 4407 Muslims less in the region in comparison with 1879, while the percentage of them decreased from $2,6 \%$ to $0,6 \%$. The biggest decrease was recorded in the Vranje county: from 3,35\% to $0,09 \%$. The Albanians from Masurica had been moved out. A large decrease in the number of Muslims is noticed also in Pirot : from $6,8 \%$ to $0,36 \%$. A bit more Muslims remained in the cities of the Niš county, although their number also decreased from $7,13 \%$ to $1,3 \%$. The Albanians stayed almost only in the Toplica county and their percentage did not change there in comparison with 1879 . It means that the Government did not disturb them and that they had started to adjust to the way of life in Serbia.

\section{Populating of the Deserted Regions}

The empty villages had been attracting the immigrants from various regions. The law about the colonization of these regions was passed, and the populating began. A lot of the 1876 war sufferers from the Aleksinac, Knjaževac and Zaječar districts had started to come into the Prokuplje district, even before the end of the war ${ }^{104}$. Families of Serbian rebels from the regions Lab and Kopaonik, who had escaped to Serbia in 1876, had settled in the vacant Albanian villages in the upper Toplica ${ }^{105}$. The Serbs, who had stayed in Lab after the 1876 war, had also moved into the new counties ${ }^{106}$. After the Berlin congress, the Serbian population from the Ibar and Vučitrn districts had immigrated into the regions around Prokuplje and Kuršumlja; those from the Vidin, Trn, Belogračik and Breznik regions, which were attached to Bulgaria, had settled in the Niš and Pirot counties ${ }^{107}$. A lot of Serbs from the sanjak of Novi Pazar had moved into Toplica ${ }^{108}$. Some Montenegrins settled in the same county, in the 1889-1890 period $^{109}$. A large part of the Serbian population from Kosovo had immigrated in Serbia after the war, under the pressure of Albanian refugees ${ }^{110}$. So, instead of Muslims, Serbs had come. There are no data about the number of immigrants. It is likely that even the Serbian authorities did not know their number ${ }^{111}$.

\section{The Question of the Muslims' Property}

After the Muslims had left, the question of their property occurred. As soon as it was established, the Serbian local administration started to collect the food remained in the empty houses and to put it in the warehouses ${ }^{112}$. Naturally, the local inhabitants had taken a part of it, before the authorities managed to collect, or even list it ${ }^{113}$. Much more important was the issue of the Muslims' real estates. In many cases, the Turks were the landowners, and the Serbian peasants were tilling the soil and they had to give a certain part of the harvest to the Turks. After the Berlin congress, the Serbian Government decided to give that land to the peasants, for Serbia was a country of free peasant's estates, but before that, a temporary solution was found. All of the Turkish state property, as well as the private land of those Muslims, who tilled it by themselves, had been rented out. The peasants who worked on the Turkish private land had to continue to do so, until the final solution was found ${ }^{114}$. In 1833 the Serbian authorities had to deal with the same problem. At that time, the Turkish land was given to the peasants who tilled it, and all of the owners' claims were included in the tribute, which Serbia used to pay to the Porte ${ }^{115}$. In 1878, the situation was different. According to article 39 of the Berlin treaty, Muslims, who did not wish to live in Serbia, were allowed

Balkanologie, Vol. II, n² 2 | 1998 
to keep their property and to rent it to other people. Besides, special Serbian-Turkish state commissions should have been formed, in order to work on all the issues related to the Turkish state, or Muslims' private property, within the three years time limit ${ }^{116}$. This article disabled the ceding of the land to peasants without any payments to its owners, and the Serbian Government did not have enough money to give compensations to the Turks. Therefore, a special "agricultural law" was passed on 3. (15.) February 1880 by which was decided that the peasants should pay for the land by themselves. Prices and payment conditions were to be established by free bargain. The peasants had misused this law in different ways, so the Government was forced to float a loan abroad and to pay off the former landowners ${ }^{117}$. A very important condition for the integration of the new regions in the Principality of Serbia was fulfilled in this way.

\section{The Consequences} going on. Different kinds of costumes and dialects could have been seen and heard in 
these areas $^{125}$. The way of life in the cities was changing, as well as the cities themselves. A church bell replaced the khoja's voice ${ }^{126}$.

\section{Conclusion}

From a wider historical point of view, the emigration of Muslims from Serbia represented only a part of the long-lasting process of their checking from the Balkan Peninsula. In that specific moment, it was a natural continuation of the modern Serbian state creation.

The 1877/1878 Serbian-Turkish war has been many times written about in the Serbian historiography. It seems, however, that the migrations initiated by the war have always been in the shade of military operations and their Berlin epilogue. They were, in fact, larger and more important than they are usually considered to have been. The opinion that 30000 Albanians emigrated from Serbia, has remained unquestioned for almost a century. That number was bigger : 49000 out of, at least, 71000 emigrated Muslims. Insufficient attention has been paid to the emigration process itself and especially to the policy of the Serbian Government towards the Muslims remaining in Serbia after the Berlin congress. Neither the consequences of this emigration have been thoroughly studied.

Our paper was not written with the ambition to find the final answers to all these questions. We have only pointed out the significance of this subject and tried to show the ways for future researches.

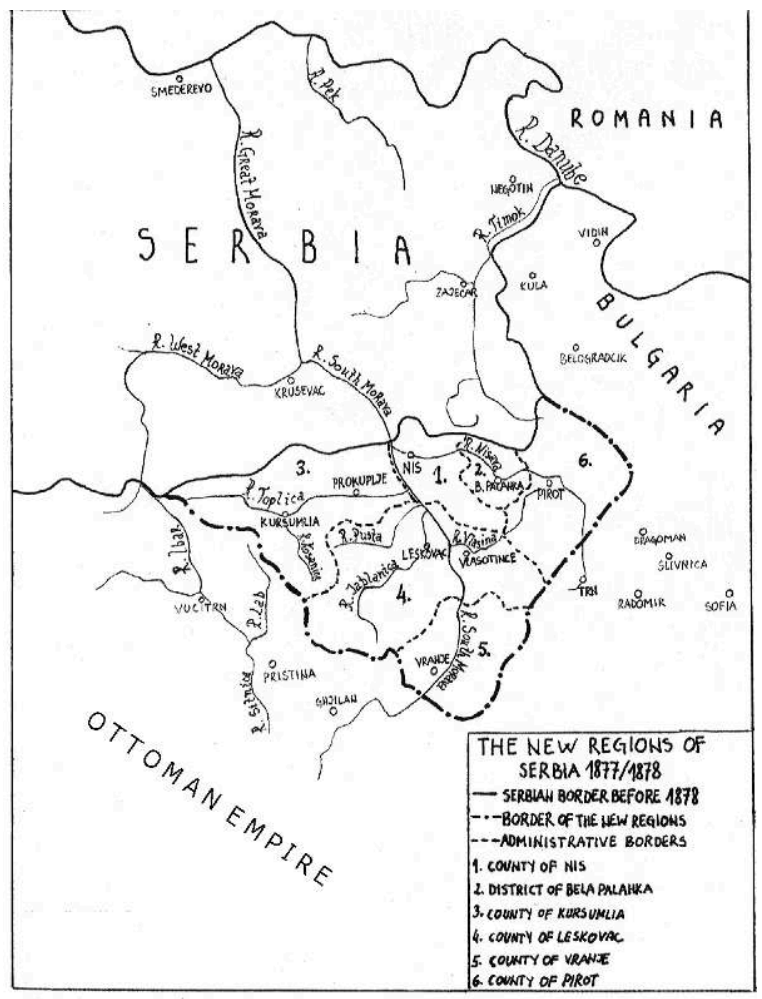




\section{NOTES}

1. Ekmečić (Milorad), Srpski narod i istočno pitanje, Istorija srpskog naroda V-1 (Le peuple serbe et la question orientale. Histoire du peuple serbe, vol. 1), Beograd, 1981, p. 525.

2. Ibid.; Čubrilović (Vasa), «Politički uzroci seoba na Balkanu od 1860-1880» (Les causes politiques des migrations dans les Balkans, 1860-1880), Glasnik Geografskog Društva Srbije, 15, 1930 ; Rizaj (S.), «Struktura stanovništva kosovskog vilajeta u drugoj polovini XIX stoleća » (La structure de la population du vilayet de Kosovo dans la deuxième moitié du XIX ${ }^{\text {ème }}$ siècle), Vranjski glasnik, 8, 1972, pp. 96-97.

3. Popov (Čedomir), Srbija u istočnoj krizi 1875-1878, Istorija srpskog naroda V-1 (La Serbie dans la crise orientale, 1875-1878. Histoire du peuple serbe, vol. 1), Beograd, 1981, p. 395.

4. Popović (V.), Istočno pitanje (La question orientale), Beograd, 1996, pp. 189-190 ; Anderson (M. S.), The Eastern Question 1774-1923, New York, 1966, pp. 185-194.

5. Jovanović (S.), Vlada Milana Obrenovića I (Le gouvernement de Milan Obrenović, vol. 1), Beograd, 1990, pp. 357-365 ; Popov (Čedomir), op.cit., pp. 396-399.

6. New Serbian borders were established by the article 36 of the Berlin treaty; Srbija 1878 (Serbie, 1878), Beograd 1979, p. 569.

7. Stojančević (V. N.), Leskovac i oslobodjeni predeli Srbije 1877-1878 (Leskovac et les régions libérées de Serbie, 1877-1878), Leskovac, 1975, p. 25.

8. Ibid., p. 9 , table 1 .

9. Rizaj (S.), art.cit., p. 105, table 1.

10. Ibid., p. 95.

11. I have doubled the number of men stated in the 1873 inventory, presuming that the number of women was approximately the same; then, the total number of inhabitants has been increased for $4,1 \%$, because that was the increase percentage in the 1873-1877 period.

12. I have applied the increase percentage of $4,1 \%$ to the data stated in the 1873 inventory.

13. Rat Srbije sa Turskom za oslobodjenje i nezavisnost 1877/1878 (La guerre de la Serbie contre la Turquie pour la liberté et l'indépendance, 1877-1878), Beograd: Vrhovne Komande Srpske Vojske, 1879, pp. 147-148.

14. Nikolić (R. T.), Širenje Arnauta u srpske zemlje (Propagation des Albanais sur les terres serbes), Beograd, 1938, p. 27.

15. Stojančević (V. N.), op.cit., p. 12.

16. Bogdanović (D.), Knjiga o Kosovu (Livre sur le Kosovo), Beograd, 1986, pp. 85-126 ; Nikolić (R. T.), op.cit., p. 5.

17. Nikolić (R. T.), op.cit., p. 29 ; Vasiljević (J. H.), « Pokret Arnauta za vreme srpsko-turskih ratova 1876 i 1877/1878 » (Le mouvement des Albanais au temps des guerres serbo-turques, 1876 et 1877-1878), Ratnik, 59, 1905, pp. 493-494.

18. Nikolić (R. T.), op.cit., p. 25 ; compare with Vasiljević (J. H.), art.cit., p. 651, footnote 1 ; Rakić (M.), «Iz nove Srbije » (De la nouvelle Serbie), Otadžbina, 4, 1880, p. 549.

19. More information about that subject : Nikolić (R. T.), op.cit..

20. Čubrilović (Vasa), art.cit., pp. 29-35.

21. Ibid., pp. 35-38.

22. Ibid., pp. 26-29.

23. Vasiljević (J. H.), art.cit., pp. 505-506.

24. Ibid., pp. 637-643; Rat Srbije sa Turskom (op.cit.), p. 151.

25. Vasiljević (J. H.), Arbanaska liga-arnautska kongra i srpski narod u Turskom carstvu (Ligue albanaise - congrès albanais et le peuple serbe dans l'empire turc), Beograd, 1909, p. 11. 
26. Ibid., pp. 11-12 ; compare with Milićević (M. Dj.), Kraljevina Srbija-Novi Krajevi (Royaume de Serbie, nouvelles régions), Beograd, 1884, pp. 361-362 ; Vasiljević (A.), Moje uspomene (Mémoires), Beograd, 1990, p. 125.

27. The dates are given by the Gregorian calendar.

28. Vasiljević (J. H.), art.cit., p. 651.

29. Stojančević (V. N.), op.cit., p. 116.

30. Vasiljević (J. H.), art.cit., p. 652 ; compare with Stojančević (V. N.), op.cit., p. 116.

31. Ibid., p. 653.

32. Turkish authorities were encouraging the refugees, convincing them that a new army was on its way to rescue them; ibid., p. 654.

33. Ibid., p. 655 ; Popov (亡̌.), op.cit., p. 403.

34. Milićević (M. Dj.), op.cit., pp. 52-53; compare with Kanić (F.), Srbija, zemlja i stanovništvo II (La Serbie, territoire et population, tome 2), Beograd, 1986, p. 238.

35. Stojančević (V. N.), op.cit., p. 90.

36. Milićević (M. Dj.), op.cit., p. 227.

37. Rat Srbije sa Turskom (op.cit.), p. 49.

38. Milićević (M. Dj.), op.cit., p. 108.

39. Stojančević (V. N.), op.cit., p. 72.

40. Rat Srbije sa Turskom (op.cit.), p. 122.

41. Ibid., pp. 146-159 ; Vasiljević (J. H.), art.cit., p. 659.

42. On 31. January 1878; Rat Srbije sa Turskom (op.cit.), pp. 111-130.

43. Stojančević (V. N.), op.cit., p. 278 , document $n^{\circ} 207$.

44. Kanić (F.), op.cit., p. 258.

45. Rat Srbije sa Turskom (op.cit.), 111-123.

46. Ibid., p. 121.

47. Nikolić (R. T.), « Poljanica i Klisura », Srpski etnološki zbornik, VI, 1905, p. 15.

48. Vasiljević (J. H.), art.cit., p. 657.

49. Ibid., p. 663.

50. The officers who supported the expulsion orders were Dj. Horvatović, M. Lećjanin, S. Binički, A. Orećković; Vasiljević (J. H.), op.cit., pp. 11-15 ; Vasiljević (A.), op.cit., p. 125.

51. Ekmečić (Milorad), op.cit., p. 526.

52. Cvijić (Jovan), Osnove za geografiju i geologiju Stare Srbije i Makedonije (Principes pour la géographie et la géologie de la Vieille Serbie et de la Macédoine), Beograd, 1911, pp. 1166-1167.

53. Pavlović (R. Lj.), «Seobe Srba i Arbanasa u ratovima 1876 i 1877/1878. » (Les migrations serbes et albanaises pendant les guerres de 1876 et 1877-1878), Glasnik Etnografskog instituta SAN, 4-6, 1955-1957 ; Cvijić (Jovan), op.cit., p. 1199 ; Stanković (T.), Putne beleške po Staroj Srbiji (Récits de voyage au travers de la Vieille Serbie), Beograd, 1910, p. 109.

54. Cvijić (Jovan), op.cit., pp. 1174-1183.

55. Stanković (T.), op.cit., pp. 31-35.

56. Ibid., p. 81 ; Nušić (B.), S Kosova na sinje more (Du Kosovo à la mer), Beograd, 1936, p. 212 ; Dedijer (J.), Nova Srbija (La nouvelle Serbie), Beograd, 1913, p. 250.

57. The refugees from Leskovac went to Mitrovica, Prizren, Kumanovo, Veles, Skoplje, Ser, Saloniki ; the refugees from Pirot went also to these cities as well as to Štip, Tetovo, Gostivar, Bitolj, Chataldza ; Milićević (M. Dj.), op.cit., p. 227.

58. Nušić (B.), op.cit., p. 214 ; Pavlović (R. Lj.), art.cit., p. 77.

59. Pavlović (R. Lj.), art.cit., p. 77.

60. Nušić (B.), op.cit., pp. 212-213.

61. Stanković (T.), op.cit., p. 81.

62. Cvijić (Jovan), op.cit., p. 1265.

63. Pavlović (R. Lj.), art.cit., p. 78. 
64. Cvijić (Jovan), op.cit., pp. 1166-1167.

65. Stojančević (V. N.), op.cit., pp. 84-86.

66. Državopis Srbije, XI, Beograd, 1882.

67. Stojančević (V. N.), op.cit., p. 84.

68. Ibid., pp. 114-130; I have compared data from the lists and made this table.

69. Ibid., pp. 115-117.

70. Rakić (M.), art.cit., p. 11.

71. Compare the method with Pavlović (R. Lj.), art.cit., p. 76 ; compare the number of houses in the Prokuplje district with Rakić (M.), art.cit., p. 11.

72. M. Rakić has traveled through the new counties just after the war ; Rakić (M.), art.cit., p. 23.

73. Ibid., p. 14.

74. Stojančević (V. N.), op.cit., pp. 89-113.

75. Ibid., pp. 104-105.

76. Rakić (M.), art.cit., p 364.

77. Stojančević (V. N.), op.cit., pp. 106-108.

78. There were 10525 male Muslims in the district in 1873. I have doubled that figure, presuming that the number of women was approx. equal as the number of men; the total number of inhabitants increased approx. for 4,1\% in 1873-1877 period. 21913 Muslims lived in the district in 1877, of whom 4880 lived in the city.

79. Rakić (M.), art.cit., p. 54.

80. The village was called Lepenica ; in 1879 all of its inhabitants were Serbs ; ibid., p. 35.

81. Nikolić (R. T.), art.cit., pp. 97-99, 109.

82. In the Poljanica district, the average number of inhabitants in one Serbian house was 7,6; I have applied that relation to the Albanian houses ; Rakić (M.), art.cit., p. 34.

83. Stojančević (V. N.), op.cit., pp. 132-143.

84. Ibid., p. 151.

85. Milićević (M. Dj.), op.cit., p. 240.

86. Kanić (F.), op.cit., pp. 204-205.

87. Stojančević (V. N.), op.cit., p. 161 ; compare with Kanić (F.), op.cit., p. 209 ; see footnote 22.

88. Ibid., p. 118 .

89. Rakić (M.), art.cit., p. 6.

90. see footnote 82 .

91. Prokuplje had 4410 inhabitants in 1873 ; the increase percentage in 1873-1877 period was 4,1\%, so it had approx. 4690 inhabitants in 1877.

92. Milićević (M. Dj.), op.cit., p. 115 ; compare with Stojančević (V. N.), op.cit., p. 90, footnote 215 ; Kanić (F.), op.cit., p. 239.

93. Rakić (M.), art.cit., pp. 36-37 ; compare with Kanić (F.), op.cit., p. 258.

94. Milićević (M. Dj.), op.cit., p. 309.

95. Ibid., pp. 107, 127 ; compare with Kanić (F.), op.cit., p. 152.

96. Ibid., p. 227 ; Kanić (F.), op.cit., p. 215 ; Rakić (M.), art.cit., p. 602.

97. Ibid., p. 240.

98. A part of the city was called "Arnaut-pazar", which means the Albanian market; Stojančević (V. N.), op.cit., p. 132.

99. Milićević (M. Dj.), op.cit., pp. xvi-xvii.

100. Ibid., pp. xvii-xviii.

101. Ibid., p. 309.

102. Ibid., p. 399.

103. Državopis Srbije, 16, 1889, pp. 256-263.

104. Stojančević (V. N.), op.cit., p. 77, document No. 94.

105. Pavlović (R. Lj.), art.cit., p. 62. 
106. Cvijić (Jovan), op.cit., p. 199 ; Stanković (T.), op.cit., p. 109.

107. Stojančević (V. N.), Etničke promene i migraciona kretanja u oslobodjenim krajevima Srbije kao posledica srpsko-turskih ratova 1876-1878, Srbija u zavr\}noj fazi velike istočne krize (1877-1878) (Changements ethniques et mouvements migratoires dans les régions libérées de Serbie en tant que conséquences des guerres serbo-turques de 1876-1878. La Serbie dans la phase finale de la crise orientale, 1877-1878), Beograd, 1980, p. 107.

108. Pavlović (R. Lj.), art.cit., pp. 87-88.

109. Kostić (M.), «Iz istorije kolonizacije Južne Srbije krajem prošlog veka » (De l'histoire de la colonisation de la Serbie du Sud à la fin du siècle dernier), Glasnik Skopskog Naučnog Društva, 12, 1933, pp. 240-241.

110. Stojančević (V.), Srbi i Arbanasi 1804-1912 (Serbes et Albanais, 1804-1912), Novi Sad, 1994, p. 143 ; Rizaj (S.), art.cit., p. 99 ; Stojančević (V. N.), Etničke promene (op.cit.), p. 107.

111. Kanić (F.), op.cit., p. 238.

112. Stojančević (V. N.), Leskovac (op.cit.), p. 48.

113. Ibid., p. 213 , document $n^{\circ} 77 ;$ p. 216 , document $n^{\circ} 174 ;$ p. 116.

114. Ibid., p. 49.

115. Jovanović (S.), Vlada Milana Obrenovića II (Le gouvernement de Milan Obrenović, vol. 2), Beograd, 1990, p. 14.

116. Srbija 1878., p. 571.

117. Jovanović (S.), op.cit. (vol. 2), pp. 14-15.

118. Vasiljević (J. H.), op.cit., pp. 6-10 ; Bogdanović (D.), op.cit., p. 149 ; compare with Kanić (F.), op.cit., pp. 334-335.

119. Vasiljević (J. H.), op.cit., pp. 16-19.

120. The Serbs from Peć sent one complaint letter to the Russian Tsar Alexandar II in July 1879, which contained a list of Serbs murdered by the Albanians during the 1875-July 1879 period; Stojančević (V.), op.cit., pp. 148-157.

121. For further information about the Prizren League see Vasiljević (J. H.), op.cit., and Bogdanović (D.), op.cit., pp. 142-148.

122. Stojančević (V.), op.cit., p. 143 ; Bogdanović (D.), op.cit., p. 148 ; Rizaj (S.), art.cit., p. 99.

123. This refers to the Muslims, naturally.

124. Vasiljević (J. H.), art.cit., p. 490.

125. Pavlović (R. Lj.), art.cit., p. 88.

126. Kanić (F.), op.cit., pp. 153-163.

\section{ABSTRACTS}

This work deals with the muslim emigration from the «new countries » of Serbia during, and after, the serbo-turkish war of 1877-1878. Muslims represented a third of the population of these areas in 1877. Muslim country population was, in majority, Albanian, whereas city population was Turkish. The biggest muslim exodus took place during military operations, only a small part of muslims has emigrated soon after. In this work, the main causes of emigration are underlined, and they indicate a deep intolerance between christians and muslims in the Balkans.

Migratory flux (whose description is depending on relying sources) follow military advances of Serbian troops. Albanians have been, intentionally, placed in Kosovo, near the new Serbo-Turkish 
frontier, whereas Turkish settled in cities in the Ottoman empire.

The author has carefully examined the number of emigrants. Since now, everyone believed that 30000 Albanians have flued from Serbia. But the author estimates that 71000 muslims have emigrated from the kingdom of Serbia, including 49000 Albanians. These numbers derived from a detailed analysis of each region and city of the "new Serbian countries ». Emigrants have been replaced by Serbs from the nearest regions of the Ottoman empire and from regions that have suffered of the 1876's war.

The muslim emigration has a deep impact on Serbia and on the Serbians. Yet, it was, at a certain time, a natural evolution in the state-building process of Serbia, which has begun in the 19th century.

\section{AUTHOR}

\section{MILOŠ JAGODIĆ}

Historien. 